\title{
銅合金の流れ誘起局部腐食に及ぼす $\mathrm{Ni}$ および Be の影響 \\ 一海生生物防污性にも耐食性にも優れた銅合金一* \\ 村上盛紀**, 矢吹彰広**, 松村昌信** \\ **広島大学大学院工学研究科
}

\author{
Effect of Ni and Be Content on the Flow-induced Localized \\ Corrosion Behavior of Copper Alloys \\ -A Copper Alloy with Both Anti-fouling and Anti-corrosion Properties - * \\ Moritoshi Murakami **, Akihiro Yabuki ** and Masanobu Matsumura ** \\ ** Graduate School of Engineering, Hiroshima University
}

\begin{abstract}
The fouling of material surface through the adhesion of marine organisms such as mussels and barnacles is a serious problem for facilities that involve the use of seawater. The use of copper alloys to avoid such fouling is promising because they release copper ions that inhibit the growth of marine organisms. However, the release of copper ions leads to the deterioration of the alloy through corrosion. Thus, these two conflicting characteristics makes the use of such alloys questionable. We describe here, however, a copper alloy that has excellent anti-fouling characteristics and is also satisfactory resistant to corrosion. The effect of two types of alloying elements, namely $\mathrm{Ni}$ and $\mathrm{Be}$, on the corrosion of a copper alloy was examined. The former would be expected to promote corrosion resistance, and the latter to serve as an anti-fouling agent. Corrosion tests were carried out in a jet-in-slit apparatus in which so-called erosion-corrosion as well as the flow velocity difference-induced corrosion can be rapidly reproduced. As expected, an increase in Ni content leads to an increase in the corrosion resistance of the copper alloy. Too high content of $\mathrm{Ni}$, however, causes pitting corrosion. Contrary to expectations, the addition of Be decreased the depth of corrosion.
\end{abstract}

Keyword : beryllium, flow-induced localized carrosion, erosion-corrosion, flow velocity difference-induced corrosion, copper

1. 緒

\section{言}

海水が用いられる設備では，海生生物の付着などによ る材料表面の污れは深刻な問題である. 例えば, 火力発 電所の復水器には, 冷却水として海水を用いることが多 いが，海水中に生息する貝類などの海生生物が導水路の 内壁に付着すると, 流路を狭めて取水障害を, ひいては 発電に支障を起こす。そのため，これらの設備は定期的 に清掃されるが，除去された貝類は多量の廃棄物になり， その処分について新たな問題が生じる ${ }^{1)}$. 従来，このよ うな污れ対策として, 有機スズ塗料を流路壁に塗って付 着を防いできた。しかし，有機スズは毒性が強いので, 使用が全面的に禁止され, その代替材料が求められてい $\Xi^{2)}$.

このような污れの主因である海生生物の付着を避ける 材料として銅合金に期待が寄せられている．特に，銅に 少量のベリリウムを加えた合金, ベリリウム銅合金を使 用すると，防污効果が高いことが分かった ${ }^{1)}$. 一般に銅 の防污効果は，材料から銅イオンが溶出するためである と考えられている.すなわち，銅イオンには毒性があり， 貝類が銅イオンを嫌って逃げる忌避行動を起こすため, その表面には付着しない3). 本報では, 材料の生物に嫌 われる性質，すなわち被忌避性を簡単のために忌避性と

\footnotetext{
* 第 47 回材料と環境討論会（山口，2000 年）で一部発表

**, T739-8527 東広島市鏡山1-4-1 (1-4-1, Kagamiyama, Higashihiroshima, 739-8527 Japan)
}

呼び，忌避性を長期間維持できる材料は，防污性を有す る材料であると考える.

ベリリウム銅合金が防污性に優れているのは忌避性に 優れているためであり，これは溶出する銅イオン量が増 加したためと思われるが，逆に銅が多量に溶出すること はその材料の耐食性が劣ることを意味する。すなわち， 銅イオンが忌避性の原因である限り，耐食性と防污性と が共に優れる材料を得ることは難しいと考えられる。 ころが，我々は耐食性と忌避性の両方に優れた材料を見 出した.さらにその理由を明らかにした。

本報では，銅合金の耐食性と忌避性のうち，耐食性に ついて検討する．特に銅合金に耐食性を改善させる不動 態化金属のニッケル，および忌避性を発現させるものの 耐食性を劣化させると考えられるべリリウムの耐食性へ の影響について報告する，腐食現象としては, 海水流動 環境下で発生する局部腐食を想定して, 流れ誘起局部腐 食のうち, いわゆるエロージョン・コロージョンと流速 差腐食について調べた。

\section{2. 試験装置及び方法}

\section{1 試 験 材料}

Table 1 に試験材料を示す. 試験材料には 3 種類の銅お よび銅合金を用いた. Type (a) は 5 種類のベリリウム 銅-ニッケル合金, Type (b) および (c) は 3 種類のベリ リウムを含まない銅-ニッケル合金である.ベリリウム を含む合金には, 純銅に $1.8 \%$ のベリリウムを添加した ベリリウム銅合金（記号： $\mathrm{BeCu}$ ），および，ベリリウム 
Table 1 Chemical composition of specimens.

\begin{tabular}{|c|c|c|}
\hline Type & Symbol & $\begin{array}{l}\text { Primary chemical composition } \\
\qquad(w t \%)\end{array}$ \\
\hline (a) & $\begin{array}{l}\text { BeCu } \\
\text { BeNi } \\
\text { Be15CuNi } \\
\text { Be30CuNi } \\
\text { Be70CuNi }\end{array}$ & $\begin{array}{l}\text { 1.85Be-Cu } \\
\text { 1.87Be-Ni } \\
\text { 1.30Be-16.4Cu-Ni } \\
\text { 1.46Be-33.0Cu-Ni } \\
0.61 \mathrm{Be}-69.0 \mathrm{Cu}-\mathrm{Ni}\end{array}$ \\
\hline (b) & $\mathrm{Cu}$ & $99.99 \mathrm{Cu}$ \\
\hline (c) & $\begin{array}{l}70 \mathrm{CuNi} \\
30 \mathrm{CuNi}\end{array}$ & $\begin{array}{l}30.2 \mathrm{Ni}-\mathrm{Cu} \\
31.6 \mathrm{Cu}-\mathrm{Ni}\end{array}$ \\
\hline
\end{tabular}

銅合金の銅の代わりにニッケルを用いたベリリウムーニ ッケル合金（BeNi）を用いた。この合金は銅を含まない ので忌避性は期待できないと思われるが，不動態化して 耐食性に優れるニッケルを用いているので，最も耐食性 に優れていると期待される，その他，銅含有量とニッケ ル含有量の耐食性への影響を調べるために, ベリリウ ムーニッケル合金に，忌避性の発現が期待される銅を $15 \% ， 30 \% ， 70 \%$ と加えた材料（Be15CuNi，Be30CuNi, Be70CuNi）を用いた。

ベリリウムを含まない合金としての，純銅 $99.99 \%$ $(\mathrm{Cu})$, 約 $70 \%$ の銅とニッケルの合金 $(70 \mathrm{CuNi})$, 約 $30 \%$ 銅とニッケルの合金 $(30 \mathrm{CuNi})$ の 3 種類の材料は, ベリリウムを添加した効果を調べるために参考材料とし て用いた。

\section{2 試験 方法}

試験装置には，すき間噴流法試験装置を用いた。この 装置では流速の高い場所が深く浸食される“いわゆるエ ロージョン・コロージョン (so-called erosion-corrosion)" と, 流速の低い場所が深く浸食される“流速差腐食 (flow velocity difference-induced corrosion) 4)" の両方に ついて同時に調べることができる，装置の概略図を Fig. 1 に示す. 試験装置は試験溶液タンク, ポンプ, 流量計 と 2 つの試験部（セル）から構成されている. 試験部の 概略図を Fig. 2 に示す. 直径 $16 \mathrm{~mm}$ の試験片が内径 1.6

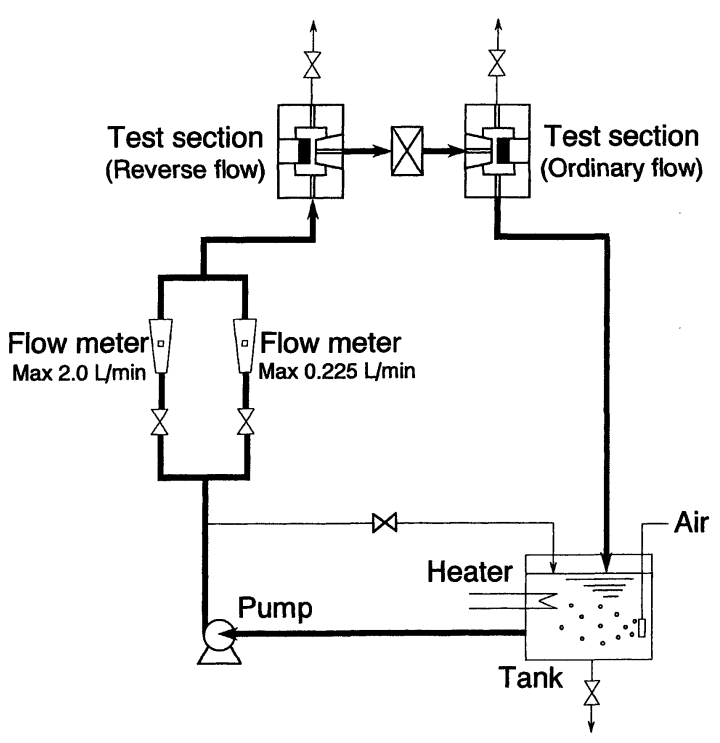

Fig. 1 Jet-in-slit testing apparatus.

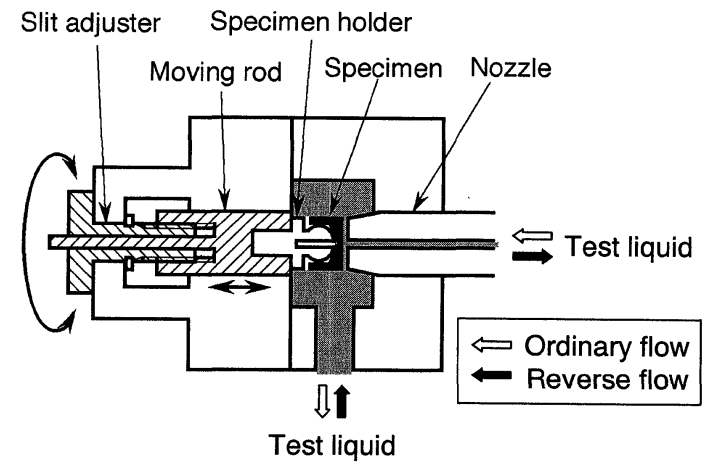

Fig. 2 Details of the jet-in-slit test section.

$\mathrm{mm}$, 外径 $16 \mathrm{~mm}$ のノズルの対面に静置されている. 試 験片は，球形の先端をもつ試験片ホルダに装着され， ～ ズル面と平行に固定された後に両者の間のすき間が 0.4 $\mathrm{mm}$ に調節される。試験装置はすべて塩化ビニル樹脂な どの耐食性非金属材料で構成されている。試験溶液を流 す方向には，ノズルから試験溶液を試験片表面に向けて 噴射し，その後ノズルと試験片表面とのすき間を満たし て放射状に流す場合（順流）と，それとは逆向きに試験 片周辺から中心に向けて試験溶液を流す場合（逆流）が ある.順流では急激な流路の拡大により激しい乱れが発 生するので, 試験片にはいわゆるエロージョン・コロー ジョンが発生する5).一方, 逆流では乱れは全く生じず, 試験片表面には流速差腐食が生じる。また，大流量で試 験溶液を流すと渦を原因とする浸食を生じさせることが できる ${ }^{6)}$. 従って, この装置を用いて試験を行うと, 実 機で生じる流れ誘起局部腐食のうち，いわゆるエロージ ヨン・コロージョンと流速差腐食を再現することができ る. 本試験装置では順流セルと逆流セルが直列に接続さ れているので，両方の試験を同時に行うことができる.

試験片表面は, エメリー紙で＃2000 まで湿式研磨した。 試験溶液には， $1 \% \mathrm{CuCl}_{2}$ 水溶液（pH : $3.5 ）$ を用い，そ の溶液温度を $40^{\circ} \mathrm{C}$ に保ち, 試験溶液内の溶存酸素濃度を 一定にするために空気飽和を行った。この試験溶液を用 いると, 海水と比べて約 200 倍の速さで腐食試験を行う ことができ，しかも得られる試験結果は定性的に海水に よる試験を充分模擬している7). 試験溶液の流量は, 0.025 0.80 L/min（ノズル出口における流速：0.21 6.7 $\mathrm{m} / \mathrm{s})$ の間に設定し, 試験時間は $1 \mathrm{~h}$ で流動試験を行っ た.

浸食の指標には, 試験前後の試験片の質量を測定し, 質量損失を試験片の暴露面積と試験時間で除した平均腐 食速度を用いた。また，浸食による表面形状の変化と， 先に得た試験片の質量損失量から最大浸食深さを算出し た．金属顕微鏡を用いて表面に形成されている皮膜の状 態の観察を行った。

\section{3. 試験結果と考察}

\section{1 ニッケルの効果}

順流と逆流におけるべリリウム-銅-ニッケル合金の平 均腐食速度と流量との関係を Fig. 3 に示す. 順流（同上 図）ではニッケルの含有量が多くなるにつれて, 平均腐 食速度が低下している，すなわち，期待した通りにニッ 

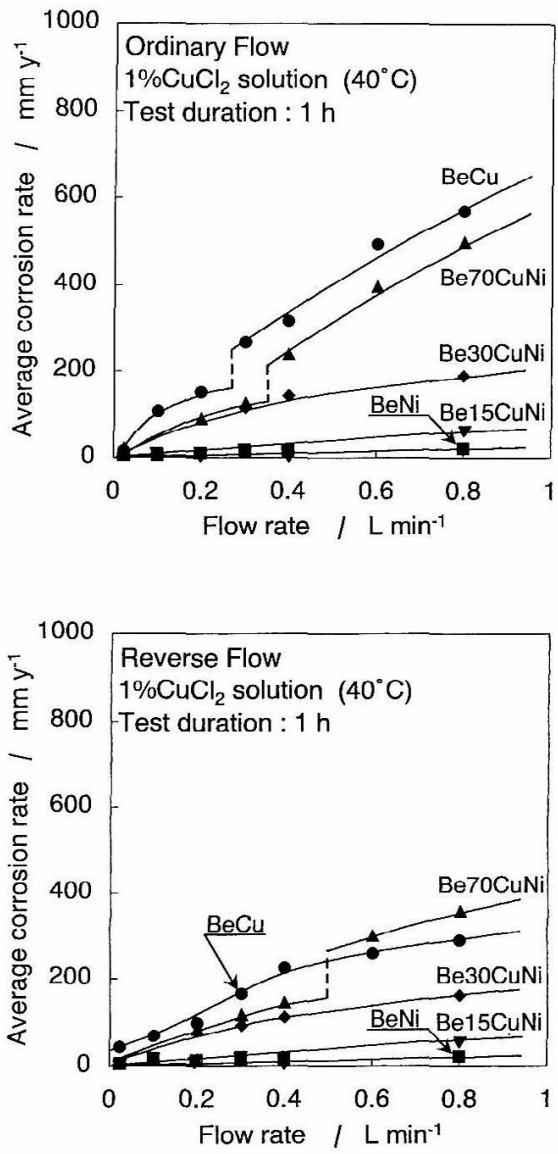

Fig. 3 Effect of flow rate on the average corrosion rate of copper alloys. Temperature, $40^{\circ} \mathrm{C}$; test duration, $1 \mathrm{~h}$. (Upper : ordinary flow, Lower : reverse flow)

ケルは合金の腐食を抑制する効果を発揮している，逆に ニッケル含有量が少ないと平均腐食速度が高いばかりで なく, BeCuと Be70CuNi ではそれぞれ約 $0.25 \mathrm{~L} / \mathrm{min}$ と $0.35 \mathrm{~L} / \mathrm{min}$ において，平均腐食速度が不連続に上昇した。 これは，これらの流量では試験片表面の保護性皮膜が剥 離されて生じる平均腐食速度の加速，すなわち，いわゆ るエロージョン・コロージョンが発生したためである8. これは, Be70CuNi の流量 $0.40 \mathrm{~L} / \mathrm{min}$ における試験後の 断面形状（Fig. 4 上図，順流）から確認できる。すな ち, 液が衝突する中心よりも，中心から $3 \mathrm{~mm}$ 離れた場 所の方が深く浸食されていた。これは，この場所で流れ の乱れが最も強くなるからである8 . 皮膜が剥離される ときの流量は皮膜の機械的強さを示している.すなわち， $\mathrm{BeCu}$ よりも Be70CuNi の皮膜が強いが，これは少量に しても含まれているニッケルの効果であると考えられ る.このようにニッケルは平均腐食速度を低下させるば かりでなく，合金表面に生じる皮膜の機械的強さを增し て，いわゆるエロージョン・コロージョンに対する抵抗 も上昇させる。

一方, 平均腐食速度が低く, いわゆるエロージョン・ コロージョンも生じなかった $\mathrm{Be} 15 \mathrm{CuNi}$ の流量 0.80 L/min に打ける試験後の形状を Fig. 5 に示す. 順流（同 上図)，逆流（同下図）ともに試験片表面にはところど ころに極めて深い孔食が生じていた。ここには示さなか ったが BeNi においても同じような孔食が発生していた. また，これらの試験片は，試験終了後でも試験片表面上

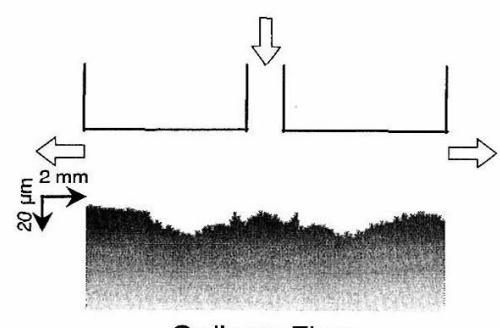

Ordinary Flow

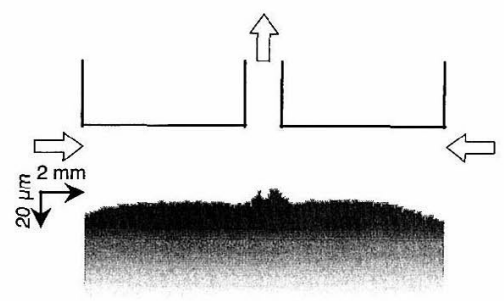

Reverse Flow

Fig. 4 Cross section of Be70CuNi specimens after a test at 0.40 $\mathrm{L} / \mathrm{min}$. Temperature, $40^{\circ} \mathrm{C}$; test duration, $1 \mathrm{~h}$. (Upper : ordinary flow, Lower : reverse flow)

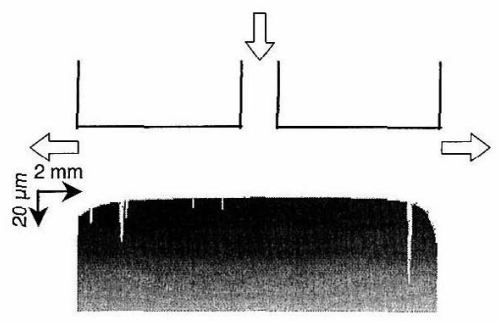

Ordinary Flow

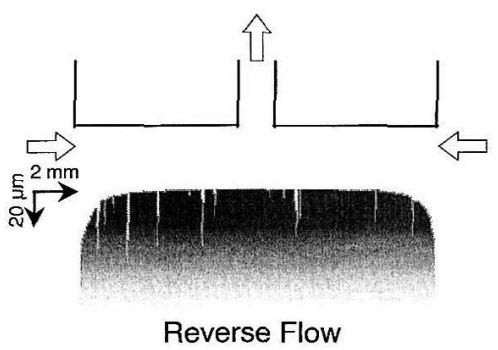

Fig. 5 Cross section of Be15CuNi specimens after a test at 0.80 $\mathrm{I} / \mathrm{min}$. Temperature, $40^{\circ} \mathrm{C}$; test duration, $1 \mathrm{~h}$. (Upper : ordinary flow, Lower : reverse flow)

には $\mathrm{BeCu}$ や Be70CuNi の表面に生じていたような皮膜 は認められなかった，従って, Be15CuNi のそれよりニ ッケル含有量を増した合金は不動態化し, 不動態化合金 の弱点である孔食が発生することが分かった。

次に逆流（Fig. 3 下図）では，順流の場合と同様にニ ッケル含有量が増すほど，平均腐食速度が低下した。ま た，試験後の試験片断面（Fig. 4 下四）を見ると，外周 部 (低流速部) での減肉が大きく, 隇肉が少なかった中 心部が逆に盛り上がっているように見える。このように 逆流では，期待通り流速差腐食が生じた。たた Be70CuNi だけが, 不連続な平均腐食速度の上昇を示し たが，その理由は次節で述べる.

ニッケルを加えると, 順流でも逆流でも不動態化して 耐食性が向上したのは当初に予想した通りであったが， 
それと同時に，不動態化する材料の弱点である孔食が生 じてしまった，孔食のような不均一腐食が発生する可能 性がある場合は平均腐食速度よりも浸食の最大值である 最大浸食深さの方が耐食性を判断する指標に適している と考えられる.

\section{2 ベリリウムの効果}

3.2.1 いわゆるエロージョン・コロージョンに対する 影響

ニッケル銅合金の耐食性に及ぼすべリリウムの影響 は，その含有量を徐々に変化させて耐食性の変化を測定 する手法ではなく，ベリリウム含有量は $2 \%$ 以下に定め (ベリリウムは高価であるため，これ以上の含有量は実 用的ではない)，それを含む材料と含まない材料との挙 動を比較することによって調べた。 また，耐食性の指標 には，上記の理由から平均腐食速度ではなく，最大浸食 深さを採用した（Fig. 6)。まず，順流では（上図）, $\mathrm{Cu}$ と $\mathrm{BeCu}$ は約 $0.25 \mathrm{~L} / \mathrm{min} に お い て ， 70 \mathrm{CuNi}$ と Be70CuNi は約 $0.35 \mathrm{~L} / \mathrm{min} に$ に扔いて最大浸食深さが不連続に上昇し た.すなわち, ベリリウムの有無は, 最大浸食深さの不 連続な上昇には関係しないことが分かった。また，当然 のことながら, 最大浸食深さが不連続に上昇するときの 流量は平均腐食速度の不連続上昇時の流量と一致してい る (Fig. 3 上図). 平均腐食速度, 最大浸食深さが不連続 に上昇する原因は，前述のように，この流量以上でのい
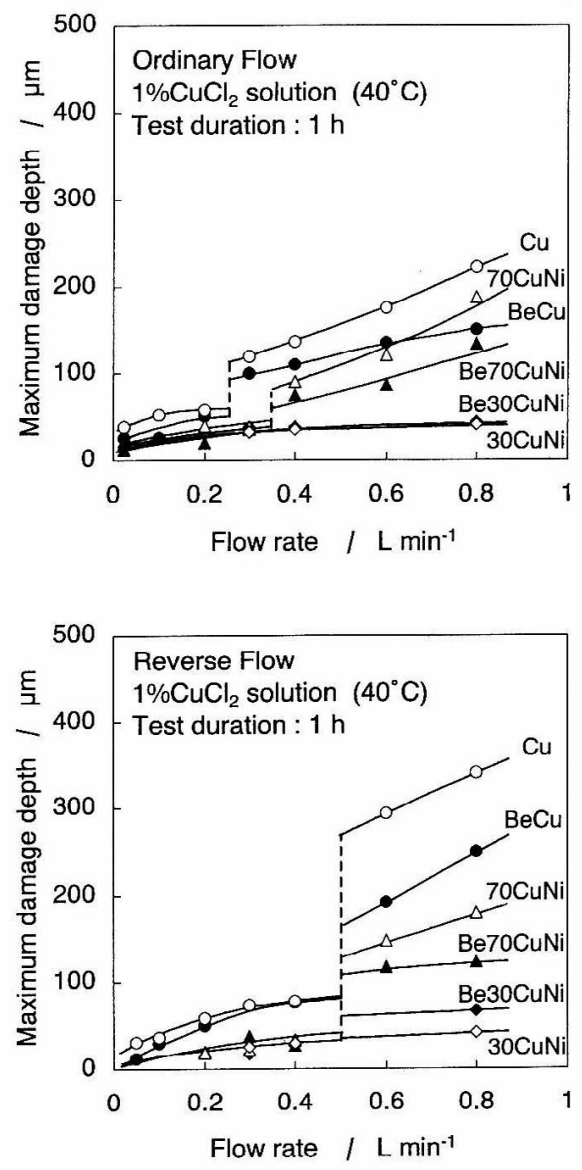

Fig. 6 Effect of flow rate on maximum damage depth of copper alloys. Temperature, $40^{\circ} \mathrm{C}$; test duration, $1 \mathrm{~h}$. (Upper : ordinary flow, Lower : reverse flow)
わゆるエロージョン・コロージョンの発生である.すな わち, 試験片表面上の保護性皮膜が機械的力によって破 壊されるからである. 従って，ベリリウムを添加しても， このときの流量が変わらなかったことは，ベリリウムは ニッケルとは異なり, 皮膜の強さを変化させるわけでは ないことを示している.

\subsection{2 流速差腐食に対する影響}

逆流では (Fig. 6 下図), すべての材料で同一の流量

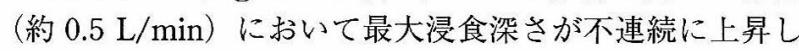
た。 $\mathrm{BeCu}$ を例に取り上げ，逆流での，流量 $0.10 \mathrm{~L} / \mathrm{min}$, および $0.80 \mathrm{~L} / \mathrm{min}$ の試験片の断面形状の比較を Fig. 7 に 示す. 流量 $0.10 \mathrm{~L} / \mathrm{min}$ (上図) では，中心部が盛り上が ったように残り，外周部の方が深く浸食している。 とこ ろが，流量 $0.80 \mathrm{~L} / \mathrm{min}$ (下図）においては，ノズル口直 下の試験片中心部に約 $300 \mu \mathrm{m}$ の極めて深い浸食が発生 している。これは，中心部に渦が発生したために生じた 浸食である ${ }^{9)}$. 渦が発生すると，渦の下では流速が極め て低く, $\mathrm{Cl}^{-}$の拡散量が少なくなる。この試験環境下 $\left(\mathrm{Cl}^{-}\right.$存在下, $\left.\mathrm{pH}: 3.5\right)$ では，腐食表面には $\mathrm{CuCl}$ の皮膜 が形成される が， $\mathrm{Cl}^{-}$の拡散量が少ないと皮膜が形成さ れにくくなる．それに対して，流速が高い場所には $\mathrm{Cl}^{-}$ の供給が豊富であるので良好な皮膜が形成され，この皮 膜は保護的に働く，従って，流速の高い場所の表面では この皮膜によってアノード反応が抑制され，一方，皮膜 のない渦の下ではアノード反応が促進される，その結果， このような深い浸食が発生する。この流速差腐食の機構 説明は渦の無い少流量のときにも適用される。ただし， その場合はノズル直下の流速は試験片外周部に比べて高 いので，そこがマクロカソードとなり，腐食速度が外周 部より低くなり，その結果，その場所が盛り上がったよ うに残る (Fig. 7 上図).

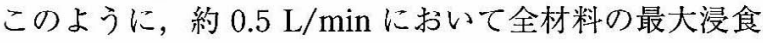
深さが一斉に不連続に上昇したのは，渦が発生したから
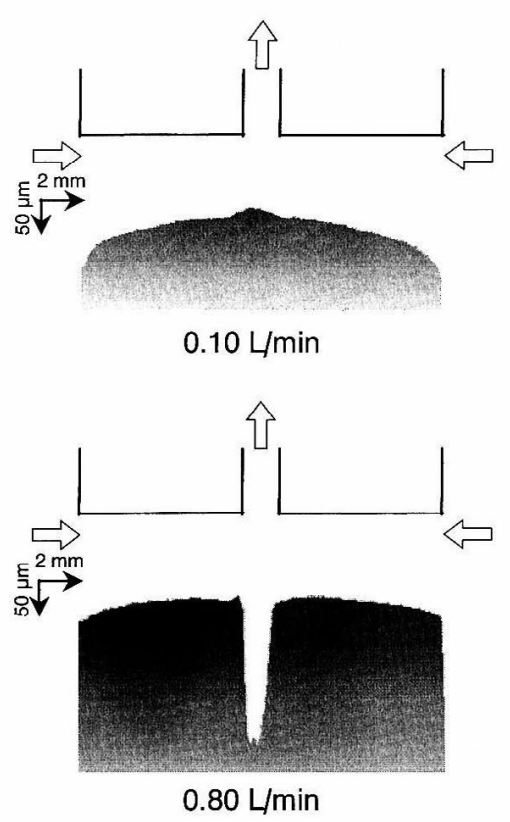

Fig. 7 Cross section of $\mathrm{BeCu}$ specimens after a test in the reverse flow. Temperature, $40^{\circ} \mathrm{C}$; test duration, $1 \mathrm{~h}$. (Upper : $0.10 \mathrm{~L} / \mathrm{min}$, Lower : $0.80 \mathrm{~L} / \mathrm{min}$ ) 

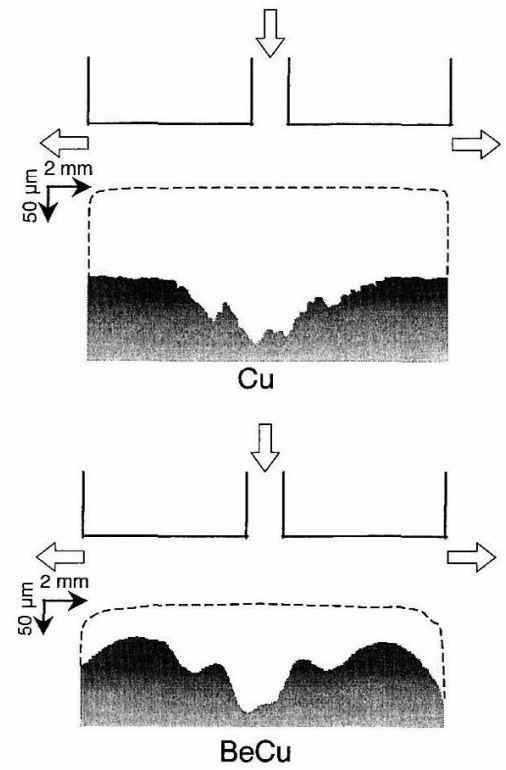

Fig. 8 Cross sections of $\mathrm{Cu}$ and $\mathrm{BeCu}$ specimen after a test in the ordinary flow at $0.80 \mathrm{~L} / \mathrm{min}$. Temperature, $40{ }^{\circ} \mathrm{C}$; test duration, $1 \mathrm{~h}$ : The solid lines show the cross section after the test, and the dashed lines before the test. (Upper: $\mathrm{Cu}$, Lower: $\mathrm{BeCu}$ )

である。すなわち，最大浸食深さの不連続な上昇は，環 境液の流動状態が原因であり，材料が原因ではない，従 って, ベリリウムは流速差腐食の発生には影響を与えな w.

\subsection{3 最大浸食深さに対する影響}

Fig. 6 において, 逆流の $30 \mathrm{CuNi}$ 以外はすべての材料 および試騃条件において，ベリリウムを含有する合金の 方が最大浸食深さが浅かった，そこで，ベリリウムを含 むと最大浸食深さが浅くなる原因を調べた。順流におけ る $\mathrm{Cu}$ と $\mathrm{BeCu} の 0.80 \mathrm{~L} / \mathrm{min}$ での試験後の試験片断面の 形状を Fig. 8 に示す. 図中の破線は試験前の試験片表面 を示している. BeCuに比べて $\mathrm{Cu}$ の方が最大浸食深さは 深い. $\mathrm{Cu}, \mathrm{BeCu}$ ともに, 中心から約 $3 \mathrm{~mm}$ の場所に, 乱れによる媣い浸食が発生していたが，中心部にも深い 浸食が発生した。これは，試験溶液の衝突速度が上昇す ると, 流れのせん断力も上昇し, その場所での腐食を加 速するためである8).このように $\mathrm{Cu}, \mathrm{BeCu}$ ともに浸食 の概括的な形状は同様であったが, 浸食面の狭い一部を 拡大して比較すると， $\mathrm{Cu}$ では多くのギザギザが認めら れるが, $\mathrm{BeCu}$ では滑らかである。

Fig. 9 に Cu と BeCu の逆流試験 $(0.80 \mathrm{~L} / \mathrm{min})$ 後の皮 膜が形成されている場所（試験片外周部）の顕微鏡写真 を示す， Cuでは，皮膜が所々薄くなっており，素地の 金属がうっすらと観察された。これに対して $\mathrm{BeCu}$ では， 試験片表面の全体に緻密な皮膜が形成されていた。ここ では省略したが，70 CuNi と $\mathrm{Be} 70 \mathrm{CuNi} ， 30 \mathrm{CuNi}$ と Be30CuNi をそれぞれ此較した場合にもべリリウムが添 加されている材料の皮膜の方が緻密に形成されていた。 従って，ベリリウムを含有すると皮膜が維密に形成され， この緻密な皮膜の形成が，ベリリウムを含む合金で表面 が滑らかに浸食され，最大浸食深さが浅く抑えられた原 因であると考えられる。

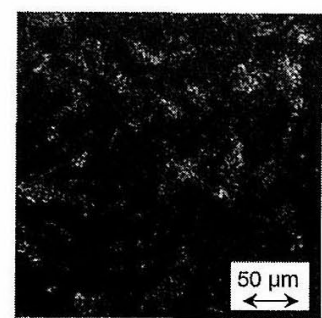

$\mathrm{Cu}$

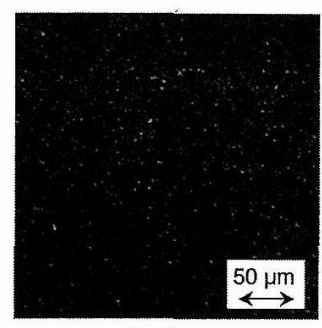

$\mathrm{BeCu}$

Fig. 9 Specimen surfaces of peripheral part after an 1 corrosion test at a $0.80 \mathrm{~L} / \mathrm{min}$.

\section{$3.370 \mathrm{CuNi}$ および Be70CuNi の特長}

先に述べたように, Fig. 3 下図では, Be70CuNi の平均 腐食速度だけが不連続に上昇した。しかし，これは， Be70CuNi は淌によって生じた穴の口径が大きかったた めに損失した体積が多く, 平均腐食速度に変化が現れた と考えられる.これに対して，その他の材料では渦によ って生じた穴は深かったものの口径が小さく, 結局損失 した質量が少なかったために不連続にト昇しなかったと 考穴られる。渦が発生したとき平均腐食速度が著しく上 昇するという Be70CuNi の特性は, 防污性材料に不利で はない，何故なら，貝が付着したとき，その場所の流れ は渦が生じたときと同じ状況になり，多くの銅イオンを 放出して，貝を遠ざける働きをすると期待されるからで ある。

また, 少流量域で $70 \mathrm{CuNi}$ と Be70CuNi の最大浸食深 さの值は, 平均腐食速度の場合と同様, 順流, 逆流とも に $30 \mathrm{CuNi}$ や $\mathrm{Be} 30 \mathrm{CuNi}$ と同じような低い值になった。 この点は，これらの合金が優れた耐食性を有しているこ とを示している。

\section{4. 結言}

本研究では, 防污性にも耐食性にも優れる銅合金を得 ることを目的とした，その内，本報ではすき間噴流法試 験装置を用いて, ベリリウム-銅-ニッケル合金の流れ誘 起局部腐食試験を行い，耐食性に及ぼすニッケルとベリ リウムの影響について調べた．得られた結果を以下にま とめる.

（1）ニッケルの含有量を増やすと，いわゆるエロー ジョン・コロージョンの発生を抑制することができる。 また，流速差や渦に起因する局部腐食に対してもかなり の抑制効果が認められる.しかし，ニッケルの含有量を 増やし過ぎると極めて深い孔食が発生する。

（2）ベリリウムを含有させると, 皮膜が緻密に形成 され浸食面の形状が滑らかになり, 最大浸食深さを浅く 抑えることができる。 
（3）これらの結果から，試験の対象となった合金の 内では, $30 \mathrm{CuNi}, \mathrm{Be} 30 \mathrm{CuNi}$ が最も耐食性に優れた材料 であると判定された。また，70 CuNi と Be70CuNi は， 少流量域において, 平均腐食速度も最大浸食深さも $30 \mathrm{CuNi}, \mathrm{Be} 30 \mathrm{CuNi}$ と同程度の低い值を示したので，こ の条件下では耐食性に優れていると判断した.

\section{謝 辞}

本研究の遂行に協力して頂いた広島大学化学工学講座 の小林康男助手に深く感謝の意を表します.

\section{参 考 文 献}

1) M. Torioya, E. Morita, K. Yamamoto and T. Mitsui, Proc. Symposium Saishin-no-mukougai-fuchaku-taisaku, p. 113, Denkika- gaku kyokai, The Electrochemical Society of Japan (1993).

2) C. Yokoji, Shikizai-Kyokaishi, 72, 704 (1999).

3) C. M. Cottorell, J.M.Dormon, T. Debies, D. G. Allen and J. K. Spelt, J. Envir. Eng., 4 , 341 (2000).

4) N. Kitashima, K. Ichikawa, K. Kinoshita and M. Miyasaka, Boshoku-Gijutsu (presently Zairyo-to-Kankyo), 35, 633 (1986).

5) M. Matsumura, Y Oka, S. Okumoto and H. Furuya, ASTM STP 866, 358 (1985).

6) M. Murakami, K. Sugita, A. Yabuki and M. Matsumura, Zairyo-to-Kankyo, 52, 155 (2003).

7) M. Matsumura, K. Noishiki and A. Sakamoto, Corrosion, 54, 79 (1998).

8) M. Matsumura, Y. Oka and H. Yokohata, Boshoku-Gijutsu (presently Zairyo-to-Kankyo), 35, 706 (1986).

9) M. Murakami, A. Yabuki and M. Matsumura, Zairyo-toKankyo, 52, 160 (2003).

(Manuscript received March 14, 2003; in final form June 30,2003 ) 